\title{
PENGALAMAN KLIEN MALARIADALAM MEMPERTAHANKAN STATUS KESEHATAN DI DAERAH KECAMATAN SUGAPA KABUPATEN INTAN JAYA
}

\author{
Hendrika Zonggonau, Blacius Dedi, Herwinda Sinaga \\ Sekolah Tinggi IImu Kesehatan Immanuel Jl. KH Wahid Hasyim No 161 Bandung \\ Email: zonggonauhendrika@gmail.com
}

\begin{abstract}
ABSTRAK
Malaria adalah infeksi parasite pada sel darah merah yang disebabkan oleh suatu protozoa spesies plasmodium yang ditularkan kepada manusia melalui air liur nyamuk. Perilaku kesehatan adalah suatu respons seseorang terhadap stimulus yang berkaitan dengan sakit dan penyakit, sistem pelayanan kesehatan, makanan serta lingkungan. Penelitian ini bertujuan untuk mengeksplorasi pengalaman klien dengan malaria.Penelitian ini merupakan kualitatif dengan pendekatan fenomenologi dengan teknik wawancara mendalam kepada enam partisipan yang berusia 20-50 tahun yang pernah terpapar malaria. Hasil penelitian didapatkan enam tema yaitu: mengenal gejala malaria, srategi mempertahankan status kesehatan, faktor linggkungan didaerah endemik malaria,modifikasi lingkungan, upaya yang dilakukan untuk mencegah penyembuhan dan kekambuhan penyakit malaria modifikasi lingkungan, program preventif malaria. Adanyafaktor lingkungan dan manusia dari daerah endemik malaria sangat memicu terjadi penyebaran malaria sehingga dapat melakukan modifikasi lingkungan agar terhindar dari paparan malaria. Usaha puskesmas untuk meningkatkan program preventif dan program kuratif dalam upaya pengelolaan klien dengan malaria.
\end{abstract}

Kata kunci : malaria; perilaku; statuskesehatan.

\section{ABSTRACT}

Malaria is a parasite infection of red blood cells caused by a protozoan species of plasmodium which is transmitted to humans through mosquito saliva. Health behavior is a person's response to stimuli related to illness and disease, health care systems, food and the environment. This study was aimed to explore the client's experience with malaria. The method used was qualitative research with a phenomenological approach carried out by in-depth interviewing techniques to six participants. Participant in this study were aged 20-50 years who had been exposed to malaria. The results of the study on malaria client experiences obtained six themes, namely: 1) Understanding the symptoms of malaria 2) The strategy of maintaining health status 3) Environmental factors in endemic areas of malaria 5) Environmental modification 4) Efforts made to prevent healing and recurrence of malaria modification 6) preventivemalaria program. The conclusion of the results of this study is that environmental factors and humans from malaria endemic areas greatly trigger the spread of malaria so that they can make environmental modifications to avoid malaria exposure. Researchers suggest District Health Centre to improve preventive programs and curative programs. For educational institutions, this research is expected to produce the best graduate students to provide nursing care to malaria clients and for the next researcher to conduct research with quantitative research methods related to the relationship between knowledge and attitudes towards malaria.

Keywords : malaria; behavior; health status 


\section{LATAR BELAKANG}

Pengalaman peneliti di usia 10 tahun pernah mengalami Penyakit Malaria. Peneliti tinggal di salah satu daerah di Desa Bilogai Kecamatan Sugapa Kabupaten Intan Jaya Papua. Malaria adalah salah satu jenis penyakit demam. Penyakit malaria yang peneliti pernah alami adalah demam menggigil. Demam menggigil diakibatkan karena peneliti mandi hujan tanpa menggunakan alat pelindung diri seperti payung dan jas hujan.

Pengalaman seorang partisispan yaitu bernama Ibu. S pernah mengalami sakit malaria. Ibu S tinggal di Nabire sejak tahun 2012 . Ibu . S sering bepergian ke Nabire untuk membeli bahan sembako. Nabire adalah salah satu daerah endemik malaria paling tinggi. Ibu $S$ pernah berobat ke Rumah Sakit Umum Nabire namun tidak sembuh total. Ibu S mengatakan malaria itu semacam penyakit rematik tulang. Ibu $S$ melakukan banyak aktifitas agar proses penyembuhan penyakit malaria pun cepat pulih kembali.

Pengalaman seorang partisipan tetangga yaitu bernama Bapak $A$ pernah mengalami sakit malaria. Bapak A malam disaat tidur tidak biasa menggunakan kelambu. Kondisi rumah Bapak $A$ pun masih tradisional honay. Bapak A kadangkadang demam disaat malam hari. Demam hanya jam tertentu seperti subuh jam 3 dan 4 di alami oleh Bapak A. Demam malaria itu seperti menggigil dalam jam tertentu saja. Demam malaria anggap biasa jika tidak berobat sangat membahayakan.

Penelitian yang dilakukan Gusra, Irawati, dan Sulastri (2013) yang dilaksanakan di puskesmas Tarusan dan Puskesmas Balai selasa kab. Pesisir Selatan terkait tentang Gambaran penyakit malaria penelitian ini menggunakan penelitian cross sectional study. Hasil penelitian memperlihatkan 18 kasus malaria terbanyak pada kelompok umur kurang lebih 15 tahun (83,3\%) sedangkan berdasarkan jenis kelamin perempuan lebih banyak terinfeksi malaria sebanyak 16 orang $(88,89 \%)$ dan berdasarkan jenis plasmodium ditemukan jenis plasmodium falciparum sebanyak 11 orang $(88,89 \%)$.

Hasil wawancara informal melalui telepon kepada Ibu A perawat pelaksana di Puskesmas
Bilogai Kec Sugapa. Pengalaman penyakit yang sering tejadi ada dua macam penyakit yang banyak di temui di tengah masyarakat yaitu penyakit ISPA dan Malaria. Penyakit malarialah yang paling berbahaya dengan kematian tinggi dari tahun 2016. Ibu A juga mengatakan kurang baiknya sarana dan prasarana transportasi di Kabupaten Intan Jaya menyebabkan susahnya daerah tersebut mendapat bantuan medis (wawancara selasa 11 April 2018). Peneliti menggunakan desain penelitian kualitatif dengan pendekatan fenomenologi. Metode penelitian fenomenologi bertujuan untuk mendapat gambaran/deskriptif tentang pengalaman hidup yang dilakukan dari sudut pandang orang yang diteliti, untuk memahami dan mengali pengalaman hidup yang di jalani (polit dan Beck, 2010).

Peneliti tertarik melakukan penelitian ini dengan metode riset kualitatif dengan pendekatan fenomenologi deskriptif dengan beberapa alasan: 1) klien yang mengalami malaria tidak hanya orang dewasa tetapi anak-anak juga terkena malaria. 2) Kabupaten Intan Jaya penyakit malaria sangat jarang terjadi tetapi pada bulan Mei tahun 2016 terjadi KLB (Kejadian Luar Biasa) hingga 36 orang meninggal. Sehingga saya ingin mengali lebih dalam lagi kejadi malaria di Kecamatan Sugapa Kabupaten Intan Jaya. 3) Kabupaten Intan Jaya ini bukan daerah endemik malaria tetapi masyarakat hampir semua pernah terkena malaria sehingga peneliti mau mengali lebih mendalam.2) memperoleh jawaban dan informasi yang mendalam, terperinci dan alamia dari partisipan tentang pengalaman mempertahankan status kesehatan dari penyakit malaria. 3) klien merupakan mereka yang membutuhkan pelayanan untuk memperoleh pelayanan kesehatan. 4) penilaian pengobatan yang dijalanikan oleh masyarakat yang mengalami malaria dapat diukur dari adanya peningkatan kesejahteraan masyarakat dari penyakit malaria dan akibat faktor resiko yang tidak terkontrol. 5) belum adanya penelitian kualitatif yang spesifik mengarah kepada klien yang mempertahankan status kesehatan dari penyakit malaria dari orang yang terkontaminasi malaria. Fenomena di atas peneliti tertarik untuk mengeksplor lebih dalam lagi mengenai pengalaman klien dewasa dengan malaria 
mempertahankan status kesehatan di Kecamatan Sugapa Kabupaten Intan Jaya Papua.

Bagaimana pengalaman klien dengan malaria dalam mempertahankan status kesehatan di daerah Kecamatan Sugapa Kabupaten Intan Jaya. Tujuan umum peneliti adalah untuk mengeksplorasi pengalaman klien dewasa terpapar malaria yang mempertahankan status kesehatan didaerah Kecamatan Sugapa Kabupaten Intan Jaya.

\section{METODE}

Desain penelitian yang digunakan adalah penelitian kualitatif dengan pendekatan fenomenologi. Penelitian kualitatif digunakan peneliti untuk mengeksplor pengalaman klien dengan malaria dalam mempertahankan status kesehatan di Kecamatan Sugapa Kabupaten Intan Jaya Papua. Partisipan yang diperlukan dalam penelitian ini berjumlah enam orang. Pemilihan partisipan dilakukan dengan teknik purposive sampling. Pemilihan partisipan berdasarkan kriteria klien dewasa berusia 20-50 yang pernah mengalami malaria.

Teknik pengumpulan data pada penelitian ini adalah pedoman wawancara dan catatan lapangan. Pedoman wawancara yang digunakan peneliti menjadi panduan peneliti dalam melakukan wawancara pada partisipan. Panduan wawancara disusun peneliti mulai dari judul, pertanyaan pembuka, pertanyaan kunci dalam penelitian, penggalian mendalam untuk pertanyaan kunci, tempat untuk mencatat komentar peneliti saat wawancara dan tempat.

Peneliti menyiapkan format catatan lapangan dengan alat tulis yang lainnya seperti pulpen dan pensil. Catatan lapangan diperlukan untuk menulis respon non verbal partisipan. Penliti menulis dengan cepat dan tepat pada saat wawancara berlangsung, karena respon non verbal ini menggambarkan kondisi psikologis partisipan. Peneliti mendokumentasikan respon non verbal yang disesuaikan dengan respon verbal partisipan.

\section{PEMBAHASAN}

Penelitian ini memperoleh enam tema utama yang memberikan suatu fenomena pengalamanKlien dengan malaria dalam mempertahankan status kesehatan di Kecamatan
Sugapa Kabupaten Intan Jaya Papua. enam tema tersebut yaitu:

Mengenal gejala malaria disebutkan semua partisipan pada penelitian ini, pada awalnya mengetahui pengetahuan tentang penyakit malaria dari tenaga kesehatan yang ada di Puskesmas Bilogai melalui penyuluhan.Klien terinfeksi malaria karena ada faktor penyebab yang menyebabkan klien dewasa terinfeksi malaria. Beberapa partisipan mengungkapkan bahwa gejala malaria yang partisipan alami seperti demam tulang-tulang sakit, sakit kepala kurang darah lemas nafsu makan menurun dan sebagainya.

Semua partisipan pada penelitian ini, pada awalnya mengetahui pengetahuan tentang penyakit malaria dari tenaga kesehatan yang ada di puskesmas Bilogai melalui penyuluhan.Klien dewasa terinfeksi malaria karena ada faktor penyebab yang menyebabkan klien dewasa terinfeksi malaria. Beberapa partisipan mengungkapkan bahwa gejala malaria yang partisipan alami seperti demam tulang-tulang sakit, sakit kepala kurang darah lemas nafsu makan menurun dan sebagainya.

Peneliti melihat gejala yang dirasakan partisipan sangat berbeda akan tetapi pada umumnya gejala yang dirasakan partisipan yang paling menonjol dari semua partisipan adalah demam. Demam yang terjadi kedinginan tiba-tiba diikuti dengan menggigil dan kemudian demam dan berkeringat terjadi setiap dua hari atau kadang hampir terus menerus.

Perjalanan infeksi malaria dalam tubuh seseorang menimbulkan manifestasi klinis yang dikenal dengan trias malaria yaitu demam, anemia, dan pembesaran limpa (splenomegali).Gejala klinis timbul setelah masa inkubasi yang dimiliki oleh setiap jenis Plasmodium berbeda-beda. Manifestasi klinisnya ditemukan keluhan prodromal sebelum terjadinya demam, seperti kelesuan, malaise, sakit kepala, merasa dingin di pungung, nyeri sendi dan tulang, demam ringan, anoreksia, perut terasa tidak enak dan diare ringan (Harijanto, 2014).

Demam malaria ataupun gejala malaria lain yang terjadi pada partisipan karena partisipan tersebut sudah terinfeksi oleh parasit didalam tubuh manusia sehingga biasa terjadi berbagai gejala malaria yang dirasakan oleh partisipan. 
Parasite yang ditularkan itu melalui gigitan nyamuk anopheles kedalam tubuh manusia sehingga beberapa hari kemudian dicetuskan melalui berbagai faktor pencetus malaria sehingga biasanya menimbulkan gejala malaria.

Hasil penelitian sebelumnya yang dilakukan di kota Pesisir Selatan oleh Tuti Gusra, Nuzulia Irawati dan Delmi Sulastri pada tahun 2013 menyatakan bahwa plasmodium falciparum banyak ditemukan di Puskesmas Tarusan. Plasmodium falciparum adalah malaria yang dapat menyebabkan banyak komplikasi dengan pelangsungan hidup yang cukup ganas, mudah resisten dengan pengobatan dan menyebabkan demam tiap 24-48 jam.

Berdasarkan penelitian ini mereka melakukan pemeriksaan dan diketahui bahwa banyak yang positif terkena malaria. Pemeriksaan dilakukan supaya upaya pemerintah dalam pemberantasan penyakit malaria bisa dilakukan di kota Pesisir Selatan.

Strategi mempertahankan status kesehatan pada partisipan penelitian ini, melakukan berbagai cara untuk mempertahankan status kesehatan agar kesehatan tetap pada optimal. Partisipan pada penelitian ini mengatakan bahwa untuk mempertahankan status kesehatannya banyak kegiatan yang mereka lakukan seperti : menjaga kebersihan lingkungan rumah di dalam maupun diluar rumah, kebersihan diri makan teratur, melakukan aktifitas fisik secara seimbang, istirahat teratur jika ada gejala sakit langsung pergi ke puskesmas terdekat atau mencegah gejala sakitnya dengan obat tradisional dan lain sebagainya. Partisipan penelitian ini mengatakan bahwa untuk mempertahakan status kesehatan dari penyakit apapun terutama penyakit malaria dapat melakukan berbagai aktifitas yaitu seperti olahraga teratur, makan teratur, dan banyak istirahat. Beberapa partisipan mengatakan bahwa tidak melakukan aktifitas malam hari seperti keluar rumah malam hari dengan tujuan untuk menghindari diri dari gigitan nyamuk. Adapun partisipan yang mengatakan menjaga kebersihan lingkungan sekitar rumah baik internal individual maupun eksternal individual seperti mandi hindari dari hujan memasang baygon di setiap pojok rumah dan minum air masak tidak langsung minum dari mata airnya.
Peneliti melihat semua partisipan untuk mempertahankan status kesehatan partisipan dapat melakukan berbagai upaya agar kesehatan meraka tetap optimal. Adapun berbagai upaya yang partisispan melakukan seperti menjaga kebersihan lingkungan halaman sekitarnya dan menjaga pola makan agar tetap sehat.Partisipan menjaga kebersihan rumah halaman sekitarnya serta mengatur pola makan juga termasuk salah satu aktifitas rutin partisipan agar kondisi kesehatan selalu tetap optimal.

Faktor yang ada pengaruhnya terhadap status kesehatan tersebut antara lain sebagai berikut: (lingkungan, prilaku, pelayanan kesehatan, dan heriditas (keturunan) di samping berpengaruh langsung kepada kesehatan, juga saling berpengaruh satu sama lainnya. Status kesehatan akan tercapai secara optimal, bila mana keempat faktor tersebut secara bersamasama mempunyai kondisi yang optimal. Salah satu faktor berada dalam keadaan yang terganggu (tidak optimal), maka status kesehatan akan bergeser di bawah optimal Becker (1979)

Faktor lingkungan dan daerah endemik malaria merupakan salah satu tema pada penelitian ini, dimana partisipan penelitian ini, mengatakan bahwa mengalami berbagai faktor lingkungan dan daerah endemik malaria seperti: faktor manusia dan nyamuk faktor lingkungan dan faktor plasmodium (agent) menyebabkan mudah tertular penyakit malaria di daerah endemik malaria mudah dan cepat nyamuk menyebar penyakit dari pada daerah non endemik. Partisipan mengatakan bahwa di Sugapa bukan daerah endemis malaria. Malaria adalah mereka yang suka bepergian daerah endemis malaria seperti di kota Timika dan Nabire. Partisipan ada juga yang mengatakan bahwa timbul malaria itu karena belum tuntas menjalankan pengobatannya dari kota daerah endemi malaria dimana awal mereka terkena malaria sehingga kambuh kembali. Ada pun partisipan yang mengatakan juga karena gaya hidup di kota yang bersuhu panas sangat berbeda dengan gaya hidup mereka yang hidup di daerah dingin seperti di Sugapa sehingga mengatur semua waktu dengan aktifitas apapun tanpa kenal lelah maka penyakit sangat mudah untuk terinfeksi di tubuh manusia dari gigitan nyamuk Anopheles. 
Peneliti melihat bahwa partisipan terinfeksi penyakit malaria bukan dari Sugapa Kabupaten Intan Jaya. Peneliti melihat partisipan yang menderita malaria karena terinfeksi parasit dari daerah endemic dimana mereka bepergian. Daerah endemik malaria adalah pusat perkembangat nyamuk anopheles . Timika adalah salah satu daerah endemik malaria yang sangat tinggi karena di kota Timika itu sendiri menjadi salah satu kota pusat perusahaan PT. Freeport pertambangan terbesar di Papua. Kemungkinan besar peningkatan wabah malaria sangat cukup tinggi dan mudah menular karena perkembangan larva nyamuk sangat memungkinkan karena adanya pengalian tambang dan lain sebagainya. Partisipan sudah terinfeksi parasit malariamaka berbagai faktor pencetus terjadi malaria sangat mudah. Sugapa bukanlah daerah endemik malaria akan tetapi bagi mereka yang terinfeksi parasite malaria disebabkan oleh faktor pencetus malaria seperti genangan air, rumah yang dekat dengan pepohonan menyebabkan kelembaban sehingga larva nyamuk mudah berkembang.

Upaya yang dilakukan untuk mencegah kekambuhan dan penyembuhan malaria disebutkan oleh partisipan bahwa dengan minum obat teratur rajin kontrol kesehatan kerumah sakit pake kelambu waktu tidur malam hari minum obat tuntas sesuai anjuran dokter dan mandi uap.

Selain itu partisipan dalam mencegah kekambuhan dan penyembuhan penyakit dapat dilakukan dengan banyak cara seperti menghindari gigitan nyamuk menjalankan pengobatan hingga penyakit tersebut sembuh total. Upaya lain yang dilakukan dengan menjalankan pengobatan tradisional hingga partisipan tersebut sembuh total dari malaria dengan cara pengobatan tradisional seperti memasak daun pepaya lalu minum air rebusannyaserta mandi uap dengan daun jambu biji. Partisipan juga selalu menjaga kebersihan lingkungan rumah didalam rumah maupun luar rumah dan tidur mangunakan kelambu saat malam hari.

Upaya yang dilakukan oleh enam partisipan untuk mencegah kekambuhan dan penyembuhan hampir semua tindakan sama. Adapun cara yang mereka lakukan untuk mencegah kekambuhan pun selalu diutamakan pengobatan tradisional karena ada yang jarak rumahnya jauh dari puskesmas dan ada juga yang memang labih percaya pengobatan tradisional sehingga mempertahankan pengobatan tradisional dan menjalankan pengobatannya.

Prinsip pencegahan malaria ada dua yaitu mencegah infeksi melalui pencegahan kontak dengan nyamuk dan pencegahan sakit apabila sudah terlanjur infeksi (Soedarto, 2008 dalam Harahap,2012). Mencegah infeksi dilakukan dengan pemberantasan vector misalnya dengan menyemprot rumah juga dengan perlindungan perseorangan, misalnya pemakaian kelambu pada saat tidur malam hari. Pemakaian kasa rumah atau obat nyamuk bakar atau lotion (Sarianto,2005).

Upaya yang dapat dilakukan untuk mencegah kekambuhan dan penyembuhan penyakit banyak cara yang dapat dilakukan. Sarana dan prasarana yang ada seperti puskesmas dan klinik sangat membantu masyarakat sehingga apapun itu penyakitnya harus pergi cek ke puskesmas terdekat. Program perefentif yang dapat dijalankan oleh dinas puskesmas seperti pembagian kelambu penyemprotan gas anti nyamuk mereka harus upayakan agar terhindar dari penyakit tersebut.

Tema ke lima hasil penelitian yaitu tentang modifikasi lingkungan. dengan memodifikasi lingkungan seperti bersihkan halaman yang kotor, tidak menggantungkan pakaian kotor didalam rumah buang sampah pada tempatnya menjaga kebersihan halaman semprot baygon dan sebelum tidur mengunakan kelambu sebelum tidur malam hari.

Partisipan mengatakan bahwa, upaya yang dilakukan untuk menghindari gigitan nyamuk seperti menyapu dilingkungan sekitar rumah.Partisipan yang mengatakan bahwa tidur malam menggunakan obat anti nyamuk (autan) tidur nyaman dari gigitan nyamuk.Ada pula partisipan yang mengatakan bahwa sebelum tdr pasang baigon bakar disetiap sudut rumah dan tidak menggantungkan pakian kotor didalam rumah dan selalu menjaga kebersihan dalam rumah dan luar rumah.

Peneliti melihat upaya yang dilakukan oleh partisipan agar terhindar dari gigitan nyamuk adalah menebang pohon yang daunnya lebat membuat halaman rumah tidak mendapat sinar 
mata hari. Peneliti melihatpartisipan tidur menggunakan kelambu saat tidur agar terhindar dari gigitan nyamuk.Peneliti melihat juga setiap bangun pagi partisipan pun rajin membersihkan halaman sekitar rumah entah dalam rumah maupun luar rumah.

Pola perilaku hidup bersih dan sehat (PHBS) masyarakat harus selalu ditingkatkan melalui penyuluhan kesehatan, pendidikan kesehatan, diskusi kelompok maupun melalui kampanye masal untuk mengurangi tempat nyamuk (pemberantasan sarang nyamuk, PSN) kegiatan ini meliputi menghilangkan genangan air kotor, diantaranya mengalirkan air atau menimbun atau mengeringkan barang atau wadah yang memungkinkan sebagai tempat air tergenang (Widoyono, 2005).

Hasil penelitian sebelum yang dilakukan di kota Lampung oleh Kholis Ernawati Budhi Soesito Artha Duarsa Rifqatussa Adah pada tahun 2010 menyatakan bahwa tujuan dari puskesmas terdekat menjalankan program prefentif yaitu untuk pencegahan, pemberantasan dan penanganan malaria dari berbagai faktor penyebab malaria tersebut membagikan kelambu dan melakukan penyuluhan tentang pengunaan kelambu supaya terhindar dari gigitan nyamuk malaria

Tema ke enam yang disajikan yaitu program preventif malaria.Enam partisispan dan enam partisipan tersebut mengatakan bahwa program preventif dan kuratif malaria yang dijalankan oleh tim kesehatan Puskesmas Bilogai seperti pembagian kelambu semprot obat anti nyamuk dan penyuluhan tentang penyakit malaria.

Semua Partisipan mengatakan bahwa pernah mengadakan program preventif yang dijalankan oleh tenaga kesehatan dengan membagikan kelambu,memasang jendela kawat,anti nyamuk. Beberapa partisipan mengatakan bahwa jarang menggunakan kelambu saat tidur dimalam hari. Ada juga partisipan yang mengatakan bahwa ada kelambunya tapi tidak menggunakannya karena kondisi rumah tidak memungkinkan (masih rumah adat). Ada juga partisipan yang mengatakan menggunakan kelambu saat tidur merasa nyaman karena terhindar dari gigitan nyamuk.
Partisipan yang tidur tidak menggunakan kelambu saat tidur malam hari kemungkinan dapat terinfeksi parasite dan bisa terjadi penularan malaria. Partisipan menggunakan kelambunya untuk aktifitas lain seperti memasang jaring ikan di sungai Wabu. Bahkan ditemukan partisipan yang dijual kelambunya ke pedagang kios dengan harga yang murah dibanding harga yang sebenarnya karena merasa tidak perlu menggunakan kelambu.

Program preventif adalah salah satu kegiatan pembasmian nyamuk malaria untuk membasmi vektor nyamuk dilingkungan sekitar rumah diluar maupun didalam rumah, penyemprotan dengan obat anti nyamuk pembasmi serangga dan serta mengoleskan obat anti nyamuk di kulit (Zulkoni, 2010 dalam Harahap, 2012)

Peneliti berpendapat bahwa, tidak menggunakan kelambu pada saat tidur malam hari membuat partisipan mudah terinfeksi parasite malaria. Penyakit malaria adalah termasuk penyakit menular dan proses penyembuhan malaria cukup lama. Program preventif yang dijalankan oleh dinas puskesmas Bilogai sangat membantu masyarakat agar mereka terhindar dari penyakit malaria maupun penyakit lainnya. Program preventif ini dilakukan setiap satu tahun sekali itupun mencegah ke-mungkinan terkena malaria. Adanya Program preventif sehingga sangat membantu untuk mencegah terjadinya gigitan nyamuk malaria tersebut

\section{KESIMPULAN DAN SARAN}

Pengalaman merupakan sumber pengetahuan, atau suatu cara untuk memperoleh kebenaran. Oleh sebab itu pengalaman pribadi pun dapat digunakan sebagai upaya memperoleh pengetahuan dengan cara mengulang kembali pengalaman yang diperoleh dalam memecahkan permasalahan yang dihadapi. Malaria adalah infeksi parasite pada sel darah merah yang disebabkan oleh suatu protozoa spesies plasmodium yang ditularkan kepada manusia melalui air liur nyamuk. Perilaku kesehatan pada dasarnya adalah suatu respons seseorang terhadap stimulus yang berkaitan dengan sakit dan penyakit, sistem pelayanan kesehatan, makanan serta lingkungan. Perlu adanya usaha 
penyuluhan yang terus menerus dari pihak Puskesmas kepada masyrakat tentang penyakit malaria dan faktor yang dapat mencegah penularan malaria.

\section{REFERENSI}

Alami, R \& adriyani, R. (2016).Tindakan Pencegahan Malaria di Desa Sudorogo Kecamatan KaliGesing Kabupaten Purworejo. Jurnal Promkes 4 (2) 199-211. Tersedia [online] https:/le-journal unair.ac.id

Creswell.(2007). Qualitative Inquiry and Research Design: Choosing Among Five Traditional. Thousand oaks. Sage publication
Gusra; Irawati; \& Sulastri.(2013). Gambaran Penyakit Malaria diPuskesmas Tarusan dan Puskesmas Balai Selasa Kabupaten Pesisir Selatan Periode Januari-Maret 2013.Jurnal Kesehatan Andalas 3(2) 234237. Tersedia [online] http://books.google.com/file/d0Bx8Ec1Qkvs puaWRDQjBoeE40d0E/view diakses pada 15 januari 2019.

Moleong, LJ.(2016). Metodologi penelitian kualitatif. Bandung: remaja RosdaKarya Notoatmodjo, S.(2014) Kesehatan Masyarakat IImu dan Seni. Jakarta: Rineka Cipta

Notoatmodjo Soekidjo. (2014). IImu Perilaku Kesehatan. Jakarta: PT. Rineka Cipta

Sugiyono. (2016). Metode penelitian kuantitatif, kualitatif, Dan R\&D. Bandung: CV Alfabeta Sutarto \& Cania, E.(2017). Faktor Lingkungan, Perilaku dan Penyakit Malaria. ArgomedUnila 4 (1) 173-184. Tersedia [Online] http:/responsitory.lppm.unila.ac.id pukul 18.0315 Februari 2019 